International Journal of Multidisciplinary Research and Development

Online ISSN: 2349-4182, Print ISSN: 2349-5979

Impact Factor: RJIF 5.72

www.allsubjectjournal.com

Volume 5; Issue 4; April 2018; Page No. 106-109

\title{
Values and local wisdom of Karonese Mengket Rumah Mbaru tradition in north Sumatera
}

\author{
Alemina BR Perangin-Angin, Robert Sibarani, Ikhwanuddin Nasution, Asmyta Surbakti \\ Postgraduate Program of Linguistics, Faculty of Cultural Sciences, University of Sumatera Utara, Medan, Indonesia
}

\begin{abstract}
A house does not only mean a place to stay but also a symbol of prosperity and prestige in Karonese perspective; in addition, it is valuable in the social and cultural life. The tradition of Mengket Rumah Mbaru (entrance to a new house) is a ceremony of gratitude to God and becomes a medium of happiness which is shared to among family members and relatives since the owners have succeeded to build their own house. This paper is descriptive qualitative and the researchers were directly involved in the ceremony to discover the local wisdom of the tradition. Since this tradition has various local wisdoms, its implementation today has undergone changes in some respects because some of its elements are intentionally eliminated, substituted or no longer held. The values of local wisdom lying in this tradition are hardworking and preseverence, cooperation and family relationship, affection and concern, solidarity and self-belonging, gratitude, thankfulness, and sharing.
\end{abstract}

Keywords: tradition, local wisdom, Mengket Rumah Mbaru, values

\section{Introduction}

People and culture are inseparable one to another and culture does not exist without people's support and vice versa. The existence and conservation of culture depend on their supporting people and in this case Sibarani ${ }^{[1]}$ argued that without its supporting people, tradition will never be presented or passed along; otherwise, they will lose their humane identity and knowledge about tradition, local wisdom and values. Norms, positive values and local wisdom can be learned from a tradition. The power that can conserve culture can come from strong commitment and from people's awareness of the importance of cultural conservation as heritage from the ancestors.

One of the traditions in Karonese people is Mengket Rumah Mbaru (entrance to a new house) which symbolizes the expression of gratitude to God and the sharing of happiness among family members and relatives. This tradition is meant to pray for God's protection toward the house and its inhabitants from any wickedness of genie and humans; so they will be blessed with abundance of sustenance, health and happiness.

The tradition of starting to live in a newly-built house has a sacred meaning to Karonese people because it is done once only in one's household life. Even though one has many houses, but this tradition is held just once. A house, to Karonese people, is taken as the symbol of prosperity, independence and a form of a serious self actualization in working. It does not only function as a shelter from heat and rain, but also as a place to gather with the whole family. This tradition is interesting to be studied because it is rich with local wisdoms, values and positive norms.

Local wisdoms can be generally defined as an idea containing local discretion and policy; and its value has been lying in the people's mind and been implemented from generations to generations. Sibarani ${ }^{[2]}$ stated that local wisdom is useful to increase welfare including (a) hard work or study, (b) dilligence, (c) discipline, (d) creativity and innovation, (e) independence and thrift, (f) education, (g) health, (h) coordination and cooperation, (i) gender management, (j) cultural conservation and creativity, and (k) environmental concern. Local wisdoms that are useful to make peace are (1) politeness (2) honesty, (3) trustworthy, social solidarity, (4) harmony and tolerance, (5) self-control, (6) commitment, (7) concern, (8) friendship and hospitality, (9) positive thinking, and (10) gratitude.

\section{Research Method}

This research employs descriptive qualitative method. The researchers were directly involved in the tradition which took place in Kuta Buluh Si mole Village in Karo Regency. The data were collected through direct interviews with knowlegeable informants and with public figures who comprehend this tradition. The data were obtained from primary and secondary sources such as documents, pictures, videos or books.

\section{Discussion}

The tradition of Mengket Rumah Mbaru is an event to express gratitude to God the Almighty and depends on the number of people participating and on the amount of cattles slaughtered. This tradition is adjusted with one's financial condition and consists of four stages, namely sumalin jabu, mengkah dapur, ngerencit, and ertukam ${ }^{[3]}$ and can be held either in small, medium or big size. A small size is called kerja singuda, sumalin jabu, susur-susur, miser-miser jabu, ngembah nakan dum and is marked with the availability of a full pot of rice. It is attended only by sangkep nggeluh or the most closely related family members and village head. There is not any previous discussion among anak beru, senina, and kalimbubu and the meal consists of only several chickens and $16-30 \mathrm{~kg}$ of 
rice; invitation is sent to approximately $50-90$ people.

A medium size is also called kerja sintengah (mengkahmengkah dapur, mengeket dapur, pindah dapur) and a discussion for a consensus (renggun) among anak beru, senina and kalimbubu is compulsory before conducting the tradition because there are many preparations. Around $160-300 \mathrm{~kg}$ of rice and middle size of cows are provided. Big size or keja sintua (ngerencit) means 'crowded' and invites many people. A discussion for consensus called sangkep nggeluh, such as anak beru, kalimbubu, and senina, is conducted before the party. Three cows or buffaloes as well as $300-350 \mathrm{~kg}$ of rice are provided and this tradition is usually held in the traditional hall called jambur. This event is entertained by singers and Karonese traditional music of gendang and perkolong-kolong. A sorcerer or guru si niktik wari determined the best day before the tradition was held. There are three criteria of the best days day, for example, nggara sepuluh aditia naik, beras pati sepuluh or cukura dua puluh because it is believed that on these days all genies residing in the house woods have gone away. Whatever the size is, many equipments should be available for instance, first, baka (made of bark to keep valuable things but it is no longer available in today ceremony equipment because people use a cupboard now), kandi-kandi (it is a kettle to keep juice of palm sugar and made of bamboo with a cap made of wood, and put on the enterance and used to prevent any genie and negative energy from entering the house), tengguli (its is half-cooked juice of palm sugar, its shape looks like candy floss, and it symbolizes that the host will be blessed with sustenance so that they will have prosperous life), enam binangun (something which is built in the house and wrapped with a piece of cloth called arinteneng and is no longer available). Next, a square brazier is provided. It has three legs made of limestone built and ignited by anak beru si majek daliken (kalimbubu from grandfather's side) in the tradition. Nowadays, daliken is substituted with gas cooker which is ignited by Kalimbubu simajekken daliken (kalimbubu nini) symbolically. Sixth, uis arinteneng (cloth) is attached on the house pillars and symbolizes serenity and peace to unite the souls of those living in the house.

Finally, anak beru simajekken dalikan gives one red hen, an egg of unpedigreed chicken, cricket (kurung), rice of one tumba (more or less 1,6 kg), palm sugar, coconuts, and bananas for gifts. Kalimbubu si erkimbang or kalimbubu has the duty to spread the mats which are called amak cur (a white mat made of thorned pandanus) and he brings rice, an egg, a hen, palm sugar, coconuts, bananas, and mattress for presents. These presents signify that the hosts bestowed abundant sustenance and do not lack of food; if one day a relative visits them, the hosts still have stock, for example, chicken to be served to the guest. The egg symbolizes fertility (narohken tendi ku rumah) and it is wished that the hosts be given abundant sustenance and many children. Rice symbolizes honesty, balance and harmony. Palm sugar, coconuts and bananas represent prosperous and good life. The white mat symbolizes a place that unites tendi (soul), so that the hosts always live in harmony and peace with no fights, and love each other. The mattress also represents comfort.

Before the event, anak beru prepares one pot of rice along with meals consisting of cooked catfish, goldfish and cricket to eat. Cricket is cooked with coconut milk until dry; it is served together with the cooked catfish and goldfish. The rice in the pot represents abundant wealth and good life so that the host are never starved. Crickets are called kurung which etimologically means covered or sheltered. Therefore, it symbolizes prayer for all blessings, welfare and health which are hoped to be available in the hosts' house and in the houses of the relatives who participate (pulung metunggung).

Anak beru puts green palm leaf (narsar lambe) surrounding the aqueduct and the leaf symbolizes happy hearts and blissfulness because the house has been completely built. Sukut (the hosts of who hold the ceremony) and anak beru collects rudang-rudang si melias gelar or leaves whose names are good from the forest such as bulung jabi-jabi (banyan tree), mbertuk (palm sugar), sangketen, padang teguh (nut grass), sanggar and its branch is tied with the bark of ambat tuah, and put in sumpit nakan (a woven bag to keep rice made of pandanus thorns). Anak beru sets up the tents at the house yard or the jambur and look for persons who bring firewoods. In the past people used woods to cook but at present they use gas or electric stove. However, some communities in some regions remain to use woods.

Anak beru provide the traditional cakes such as cimpa lepat, cimpa rambe-rambe, beras duhumen (sticky rice flour soaked in coconut milk and added with palm sugar and served for four consecutive days, banana and red sugarcane cut into small pieces are served on plates). Cimpa lepat, cimpa ramberambe, and beras duhumen represents joyous life and prosperity. A day before the ceremony, a sorcerer is asked to sleep in the new house, lits the light, pays attention around the house and has some visions whether the house is free from negative things. The sorcerer also covers the house pillars with uis arinteneng which is also attachéd on the house wall very early in the morning as the house decoration or curtains. This belief is no longer applied. On the day the hosts only asks for help from some people to take care of their house before the party is held without covering the house pillars because the construction of house nowadays have become more various that some of them do not have pillars inside the house. Anak beru spreads a mat for the guests' seats for the party on the next day.

The party starts early in the morning at around 5 a.m. like the Karonese proverb "even before flying birds go out from their nests or before the sun rises". It is believed that doing something early in the morning means that the sustenance of the host rises as the time goes by, like the sun rising higher and higher. There is a shift concerning the ritual time that normally, it starts at around 6 or 7 a.m. depending on mutual agreement.

The hosts get ready and kalimbubu si mada dareh and kalimbubu bena-bena put ose on the hosts. Ose is traditional clothes becomes the honorary clothes, which are usually worn in the events of grief. It is also a symbol of appreciation from sukut (a host, the host' siblings or anak beru) to the hosts (husband and wife). The hosts wear complete traditional clothes like a bride and groom with the accessories kelamkelam as the veil or head cover, sertali (golden accessories) as the necklace of accessories on the veil, uis rambu-rambu emas as jujungen or the cover of the veil, golden earrings in the shape of kodong-kodong (banana blossom), golden cincin tumbuk as the ring, uis nipes folded in two with equal length 
to be tied on the waist, ragi jenggi as the belt. Then, the person who carries kampil indong-indong (a container for betel filled in by lime) and prepares it is the host's mother, who also prepares grandma (the container for the betel), gambier, 5 or more or less 50 kepit (pieces of) belo (betel), tobacco with petak ranto (its container), and her left hand also carries sampen benang mbentar/benang meciho (white thread).

The husband wears complete traditional clothes consisting of uis nipes functioning as the head cover (bulang) and sertali encircling the bulang-bulang, uis nipes also functioning as kadang-kadangen which is put on the shoulders, sertali is also used as a necklace, gelang sarong is used as the bracelet for the right hand, cincin tapak gajah or tumbuk as the ring, uis arinteneng as the sarong, kampoh (sarong) ermas-emas as the sash, and ragi jenggi as the belt. If kalimbubu has a daughter who is termed

beru singumban, and a son (if any), they also wear traditional clothes. They follow ose but they do not wear emas-emas. Ose is prepared by people called sukut. Sukut (the brother of the host and his wife) also participates in ose, but they do not wear emas-emas.

Kuh sangkep means gathering in the old house. All equipment brought to the new house is prepared, such as slab used for grinding spices carried by kalimbubu from the wife's side, which represents a prayer wishing that the host had strong belief as strong as the slab. The pot full of cooked rice and other food (catfish, goldfish, cricket) is carried by anak beru. The kettle full of drinking water is carried by anak beru. The container for rice, container for clothes and mattress may be carried by anyone. Man duhumen rice is carried by anak beru. Sugar and coconuts are carried by anak beru. Amak cur (mat made from pandanus thorns) is carried on the head of sukut (the host's sister). Kandi-kandi (bags) filled of tengguli (molasses) and sugarcane are carried by young unmarried ladies. Wax gourd is carried in uis arinteneng by young unmarried ladies. Rudang-rudang simelias gelar is carried by female anak beru.

After the preparation is completed, they arrange the formation. The first row consists of the host, husband/wife and children. The firstly step out of the old house by their right feet and then lak-lak galoh stabar (tree barks of a kind of banana) are prepared i.e. 11 pieces (more or less 3 finger width) and are stepped on. It is firstly stepped on by the wife, followed by the husband and children. There are times when the first row consists of kalimbubu from the wife's side called si njujung batu penggilingen (kalimbubu who carries slab used for grinding spices), followed by kalimbubu simada dareh, kalimbubu si erkimbang (the wife's parents), kalimbubu si enterem, sembuyak, senina, and anak beru. After the order is given, they altogether leave for the new house.

When they arrive at the front door or terrace, anak beru welcomes the host with erputar (smearing a kind of rice flour mixed with water, flowers and leaves) by giving putar i.e. sap of frangipani flower mixed with betel water which has been added by lime and gambier (a kind of tannin) stirred with the stem of cassava leaves in a bowl. Putar is attached on forehead. Then, before stepping into the new house, they are obliged to take one step after another started with the right foot on the banana tree bark, magnet and stem of kempawa (a kind of palm; this activity means that all negative energy will go away, tendi (soul) of the people ho will live in the new house will be peaceful and blissful. Then every corner in the house is splattered with perbasbas i.e. leaves of besi-besi, sangka sempilet, and daun kaling juhang tied into one bundle while opening all doors and windows to send away all genies and negative energy in the house. Then, the house is encircled for 11 times while ralep-alep by cheering yelling "alep-alep", "alep-alep."

Every one gets into the house, kalimbubu welcomes by cheering yelling "alep-alep", "alep-alep." and smearing rice (page situnggong) taken from a woven bag called sumpit while saying enda ku ambor beras page situnggong gelah metunggong kita pulong kerina, "here I smear rice of si tunggung so that we altogether will lack of nothing". This is used to send away all evil things. Then the kalimbubu yells "alep-alep!" for 11 times 11 kali while yelling the first "alepalep!" with "Sada tendita ku rumah" meaning that we are all one soul in this house; the second "alep-alep!" the third (...) the fourth selpat nipi gulut (all nightmares be gone!), the fifth "enggo ertima kita kerina kita kerina i rumah" (All of us have gathered in the new house), the sixth "engo sigelem kerna ulihta latih" (all of us enjot our hard work), the seventh "pitut liah-liah sai mara ku rumah tendi" (all bad things be far away), the eighth "enggo ernaroh tendi ta rumah enggo ertima anak beru ras simbuyak, kambubu ras sembuyak" (good souls have been accompanied by relatives so all members of the family can gather in the new house), the ninth "nilah kerina liah-laih kita ku rumah mbaru" (all diseases and bad things be gone), the tenth bunoh nipi si la teng-teng (all nightmares be diminished), the eleventh "sada kerina ukurto ersada arihtaanak beru senian bagipe kalimbubu" (all of us have one soul and opinion), the yelling alap-alap 11 times "selpat nipi gulut" (all nightmares be gone), "enggo pulung kerina kuh sangkep" (all relatives have gathered here), "enggo keri kerina latih" (all tiredness be gone). "pitut liah-liah" (all difficulties be solved)."Nilah kerina sila teng-teng" (all bad powers be gone)."Ersada kerina perukuren"(all thoughts be united). Kalimbubu welcomes the host by smearing rice onto them and to the rooms.

Inside the house, kalimbubu erkimbang (cousins from mother's male relatives) directly prepare a mat for the host to sit. Then everyone sits. Anak beru distributes duhumen i.e. rice that has been soaked in coconut milk added with palm sugar to everyone that has come. In addition, pulp of coconut that is eaten with brown sugar, red sugarcane and banana that are cut small. Cimpa Lepat (food made from sticky rice fluor, sugar and coconut wrapped in ban ban leaf) and cimpa unungunung (food made from sticky rice fluor, sugar and coconut flakes fried without oil wrapped insingkut leaf), cimpa jergok (a kind of cake wrapped in kalingjuhang leaf), cimpa ramberambe (cimpa which shape looks like rambe fruit), cimpa matah (flour, brown sugar, pepper, salt and coconut mixed without cooking) are also provided.

While holding the party, the host pays the wage of the people who hhave worked to hel conducting the party by giving a cock or manok Megara; the cock is slaughtered and its blood run on the utensils; representing a wish so that the utensils will not harm the owner when they are used one day. The host also gives 4.5 kilograms of rice put in a woven bag called sumpit along with an egg, sugar, betel, cigarette and some money. 
Meanwhile, anak beru simajekken daliken (anak beru who sets up the brazier for cooking) or kalimbubu bena-bena (kalimbubu who is grandfather's cousin fro the husband side) and kalimbubu simada dareh (brothers from wife's side); followed by kalimbubu si erkimbang dire ctly goes to the kitchen to set up the brazier. They firstly twist a white thread (benang teng) to their hands, then dig a hole on the ground to build the brazier and to plant a magnet to deter dangers and to absorb negative things, as well as belo bujur (betel, areca palm, lime and gambier); the betel has to be from the kind of belo cawer (the best betel without any defect) as the symbol of a sincere and clean heart. After that, bulung-bulung si melias gelar are slipped in the four corners of the kitchen and cimpa gabor-gabor (rice fluor is thrown on them). The brazier in the right side is built by kalimbubu bena-bena, the one in the middle is built by kalimbubu simada dareh, and the one in the left side is built by kalimbubu si erkibang. It means that all of them help and support one to another and rice is coagulated and put on each of the brazier. Then the brazier is used to boil naroh manok mulia (egg). The egg is brought by kalimbubu. Then after, kalimbubu memotong slaughters a yellowish hen called manok simelias rupa by grilling the hen's head and cooking the other parts of the hen as manok sangkepen with coconut milk and spices which is then arranged to form the shape of a hen representing union in the family, an egg of pedigreed chicked naroh manok mulia) is added which will be served on a wide white plate made of ceramics or pinggan pasu for the host.

The egg is peeled by the a sorcerer or guru si baso to see whteher its content is good or not, and to ensure that there is not any hole or flat. If the shape of the egg is good, the house and hosts are believed to be good. The host eats manok sangkep and the egg on pinggan pasu covered by uis sarinteneng atau uis julu, and eat from one plate with their parents and children. They listen to manok sangkepen, and are not allowed to bite the bones. After that, they drink juice of palm sugar. Manok sengkepen that are left by the host is to be distributed to kalimbubu, aftr they finish eating, a piece of betel, a small amount of rice, a piece of turmeric and 11 grains of pepper is put on pinggan pasu without washing them. Then the plate is kept on the cupboard and may not be stepped upon. The bones left are collected on piring pasu and are kept for four days and nights and it is thrown after then.

After that, everyone are seated and eat together the rice served in a pot (nakan dem), the food prepared for eating with rice are goldfish or catfish cooked in spices, with kurung or cricket. The dinner is followed by giving advice and speeches to the hosts.

\section{Conclusions}

It can be concluded from the description of the tradition of mengket rumah mabru di atas that this tradition is rich in local wisdoms. Every procession of this tradition is held collectively because everyone involved are members of the family (kinship). Kalimbubu, senina and anak beru participate as a form of affection, concern and respect. It is also a symbol that karenese people revere the values of familyship, concern, cooperation and solidarity. All prose and other materials used in the ceremony of Mengket Rumah Mbaru contains good significance and prayers to the hosts as well as the house lived in so that it provides comfort and kindness to the hosts that they will be able to work and earn more sustenence.

The success in building a house is one's achievement gained individually by hard work and preseverence. However, this success is also obtained because of the blessings from God the Almight and family support. Therefore, the conduct of this tradition is a form of happiness sharing with family and relatives; and a form of gratitude to God the Almighty.

\section{References}

1. Sibarani Robert. Kearifan Lokal: Hakikat, Peran, dan Metode Tradisi Lisan. Jakarta: Asosiasi Tradisi Lisan, 2012.

2. Sibarani Robert. Pembentukan Karakter Langkah-langkah Berbasis Kearifan Lokal. Jakarta: Asosiasi Tradisi Lisan (ATL), 2014.

3. Prinst Darwin. Adat Karo: Medan. Bina Media Printis, 2014. 